\title{
Biomedical Waste Management: The Challenge amidst COVID-19 Pandemic
}

\author{
Arghya Das ${ }^{1}$ Rahul Garg1, Bisweswar Ojha² Tuhina Banerjee ${ }^{1}$
}

\footnotetext{
${ }^{1}$ Department of Microbiology, Institute of Medical Sciences, Banaras Hindu University, Varanasi, Uttar Pradesh, India

${ }^{2}$ Department of Pharmacology, Institute of Medical Sciences, Banaras Hindu University, Varanasi, Uttar Pradesh, India
}

Address for correspondence Tuhina Banerjee, MD, DNB, PhD Department of Microbiology, Institute of Medical Sciences, Banaras Hindu University, Varanasi 221005, Uttar Pradesh, India (e-mail: drtuhina@yahoo.com).

of waste generated during treatment/diagnosis/quarantine of COVID-19 patients. ${ }^{7}$ These guidelines have advocated use of double layered bags (using two bags), mandatory labeling of bags and containers as "COVID-19 waste," regular disinfection of dedicated trolleys, separate record keeping of waste generated from COVID-19 isolation wards, in addition to the recommendation for following existing practices of BMW Management Rules, 2016. Although the СРCB is the nodal agency for making any recommendation pertaining to BMW in India, some guidelines have also been published by other government agencies for the management of COVID-19 waste. While the latter guidelines must conform with the recommendations made by $\mathrm{CPCB}$, disparities have been noted in some with respect to the segregation norms of existing BMW Management Rules, 2016 in which the segregation of the items is devised based on the final mode of treatment. This abrupt change in the category of certain BMWs might result in inappropriate final treatment.

Addition of spill management from the BMW bags or containers, recommendation of ideal PPE for persons handling BMW, provision of health check-up for those individuals may be considered in the upcoming guidelines by СРCB. Other government agencies should clearly state in their own guidelines that the norms laid by $\mathrm{CPCB}$ should be followed for BMW management with mention of the specific URL of the CPCB guidelines. Besides maintaining uniformity in the guidelines, the monitoring of implementation of the prescribed policies for BMW management should also be prioritized. Hospitals and institutions should expand their capacities to transport and store BMWs owing to increase in the quantity of the waste. An electronic communication mechanism should be in place to specify the exact quantity of "COVID-19 waste" in different categories, any breach during transportation and treatment which should be notified to the nodal agency. Institutional infection prevention and control team should conduct regular training of all concerned staffs for BMW management and monitor the practices. These steps in combination with strict adherence to the norms will ensure better handling of the impending crisis.
License terms

ISSN 0974-2727. 


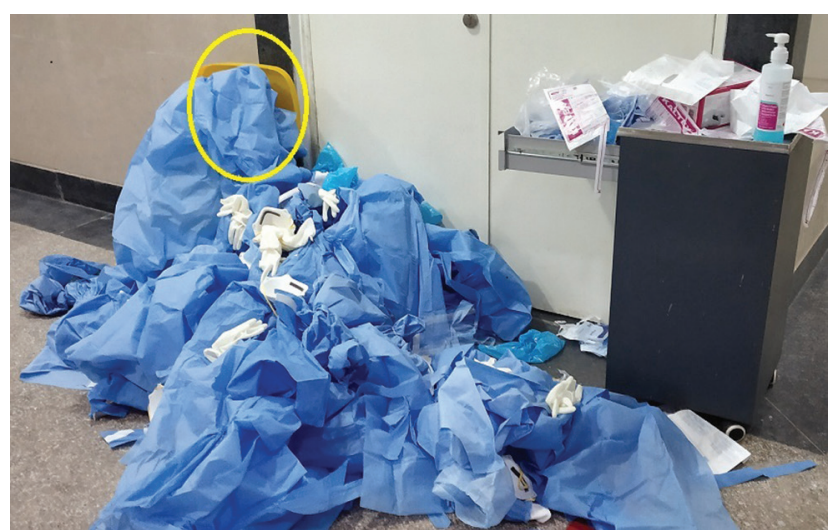

Fig. 1 Overflowing of biomedical waste in the doffing area outside a COVID-19 isolation facility in India (the barely visible yellow biomedical waste bin is hidden behind the pile of personal protective equipment). COVID-19, coronavirus disease 2019.

As is evident from the current situation of the pandemic, basic infection control practices are the only measures for containment. Proper waste disposal is an integral part of these control measures. Through this letter, the authors intend to draw the attention of the concerned authorities at the institutional and local administrative levels for thorough implementation of the prescribed policies with the scope of overall improvement in the BMW segregation and disposal in daily practice which will be of immense help even after the pandemic.

\section{Conflict of Interest}

There is no conflict of interest.

\section{References}

1 Ministry of Environment, Forest and Climate Change, Government of India. Biomedical Waste Management Rules-2016. New Delhi; 2016. Available at: http://www.
indiaenvironmentportal.org.in/files/file/BMW\%20Rules,\%20 2016.pdf. Accessed April 25, 2020

2 Ministry of Environment, Forest and Climate Change, Government of India. Biomedical Waste Management (Amendment) Rules-2018. New Delhi; 2018. Available at: http://www.indiaenvironmentportal.org.in/files/file/Bio\%20 medical\%20waste\%20management\%20(amendment) 183847. pdf. Accessed April 25, 2020

3 Singh A, Unnikrishnan S, Dongre S. Biomedical waste management in India: awareness and novel approaches. Biomed J Sci Tech Res 2019;13(4):10089-10091

4 World Health Organization. Rational use of personal protective equipment (PPE) for coronavirus disease (COVID-19). Interim Guidance. World Health Organization; 2020. Available at: https://apps.who.int/iris/bitstream/handle/10665/331498/ WHO-2019-nCoV-IPCPPE_use-2020.2-eng.pdf. Accessed April 25,2020

5 Ministry of Health and Family Welfare, Government of India. Novel Coronavirus Disease 2019 (COVID-19): Guidelines on Rational Use of Personal Protective Equipment. Available at: https://www.mohfw.gov.in/pdf/ GuidelinesonrationaluseofPersonalProtectiveEquipment.pdf. Accessed April 25, 2020

6 World Health Organization. Modes of transmission of virus causing COVID-19: implications for IPC precautions recommendation (COVID-19). Scientific brief. World Health Organization; 2020. Available at: https://www.who.int/ news-room/commentaries/detail/modes-of-transmission-of-virus-causing-covid-19-implications-for-ipc-precaution-recommendations. Accessed April 25, 2020

7 National Centre for Disease Control, Ministry of Health and Family Welfare, Government of India. Guideline for quarantine facilities COVID-19. New Delhi; 2020. Available at: https:// ncdc.gov.in/WriteReadData/1892s/90542653311584546120. pdf. Accessed April 25, 2020 